\title{
ANALISIS BIBLIOMETRIK: PERKEMBANGAN PENELITIAN DAN PUBLIKASI MENGENAI KOORDINASI PROGRAM MENGGUNAKAN VOSVIEWER
}

\author{
Pisuko Herawati ${ }^{1}$ ), Sawitri Budi Utami ${ }^{2}$ ), Nina Karlina ${ }^{3}$ ) \\ 1, 2, 3) Program Studi Pascasarjana Administrasi Publik Universitas Padjadjaran, Sumedang, Indonesia \\ 1)pisuko19001@mail.unpad.ac.id, ${ }^{2)}$ sawitri.budi@unpad.ac.id, ${ }^{3)}$ nina.karlina@unpad.ac.id
}

\begin{abstract}
ABSTRAK
Analisis bibliometrik adalah metode yang populer untuk mengeksplorasi dan menganalisis sejumlah data ilmiah. Artikel ini merupakan analisis bibliometrik yang menggunakan jurnal terindeks scopus tentang koordinasi program dengan menggunakan aplikasi VOSviewer. Tujuan analisis bibliometrik dalam penelitian ini adalah untuk mengetahui perkembangan kajian terkait koordinasi program. Secara khusus, artikel ini membahas perkembangan kutipan, tren publikasi, kolaborasi penulis, judul istilah tren, kata kunci penulis istilah tren, abstrak istilah tren, dan statistik negara dengan topik koordinasi program tahun 1943-2021. Data dikumpulkan dari database Scopus dengan menggunakan kata kunci "coordination program." Kemudian penulis menggunakan software VOSviewer untuk menganalisis dan memvisualisasikan database yang diperoleh. Hasil penelitian menunjukkan bahwa hasil analisis sitasi menunjukkan jumlah kutipan per tahun dari 1943-2021 adalah 4.304 kutipan. Irvine, M.K merupakan peneliti yang memiliki produktivitas terbesar yaitu sebanyak 10 publikasi. Pada analisis trend term Author keywords dapat diketahui bahwa terdapat 676 kunci penulis yang digunakan dalam artikel yang dipilih dengan menggunakan minimal 5 kejadian, menghasilkan 9 kata kunci penulis memiliki koneksi yang kuat. Istilah "care coordination" adalah istilah yang paling sering digunakan oleh penulis sebanyak 23 terusan. Kemudian, negara yang menerbitkan artikel koordinasi program paling banyak adalah United States dengan 246 artikel.
\end{abstract}

\begin{abstract}
Bibliometric analysis is a popular method for exploring and analyzing large amounts of scientific data. This article is a bibliometric analysis using Scopus indexed journals on program coordination using VOSviewer application. The purpose of bibliometric analysis in this research is to identify the development of studies related to program coordination. Specifically, this article discusses citation developments, publications trends, authors' collaboration, trending term titles, trend term author keywords, trend term abstracts, and country statistics with the topic of program coordination 1943-2021. The data was collected from Scopus database using keyword "coordination program." Furthermore, the author uses VOSviewer software to analyze and visualize the database obtained. The results showed that the results of the citation analysis showed the number of citations per year from 1943-2021 was 4.304 citations. Irvine, M.K is a researcher who has the largest productivity, which is ten publications. In the analysis of the trend term author keywords, it can be seen that there are 676 author keys used in selected articles using a minimum of five events, resulting nine author keywords that have a strong connection. The
\end{abstract}

\section{ARTIKEL INFO}

Diterima: 9 Desember 2021

Direvisi: 20 Desember 2021

Disetujui: 30 Desember 2021

\section{KATA KUNCI}

Bibliometrik

Coordination Program

Scopus

VOSviewer

\section{KEYWORDS}

Bibliometric

Coordination Program

Scopus

VOSviewer 
term "care coordination" is the term most frequently used by the author with 23 entries. Moreover, the country that published the most program coordination articles was the United States with 246 articles.

\section{Pendahuluan}

Koordinasi merupakan bagian penting dari administrasi yaitu sebagai prinsip pertama organisasi yang termasuk di dalamnya semua prinsip yang berada di bawahnya serta bagaimana proses beroperasinya. Namun, koordinasi hanyalah sarana dan bukan tujuan itu sendiri. Koordinasi bukanlah kegiatan yang terpisah melainkan suatu kondisi yang harus melalui semua tahapan administrasi (Marume and Jaricha 2016). Koordinasi memiliki makna yang cukup rasional pada konteks pemerintahan memiliki sejumlah aspek dan kompleksitas lain yang perlu dipertimbangkan seperti halnya kerjasama, koherensi, kolaborasi dan integrasi, oleh karena itu perlu kerjasama yang padu antar pihak terkait. Koordinasi bukan merupakan masalah politik dan administrasi sederhana, karena dapat menimbulkan berbagai masalah dalam sektor publik, khususnya dalam hal kerjasama dalam berkoordinasi. (Bouckaert, Peters, and Verhoest 2010).

Kebijakan administratif berupa pernyataan umum yang memuat tujuan, sasaran, dan berbagai sarana, untuk dilaksanakan, perlu diterjemahkan ke dalam program-program yang bersifat operasional (Tachjan, 2006). Program merupakan turunan dari kebijakan yang tidak hanya berisi tentang penjelasan mengenai tujuan/sasaran kebijakan yang ingin di capai, melainkan secara rinci menggambarkan tentang prosedur, metode, standar, dan sumber daya yang akan digunakan.

Penelitian merupakan proses mengumpulkan dan menganalisis data secara sistematis dalam mencapai tujuan tertentu. Evaluasi obyektif kegiatan penelitian tergantung pada ketersediaan data dari kegiatan penelitian ilmiah. Pada tahun 1958, Eugene Garfield mendirikan Institut Informasi Ilmiah, yaitu sebuah organisasi yang kemudian mendirikan Science Citation Index (SCI). SCI merupakan database referensi besar pertama yang memperkenalkan faktor dampak yaitu indikator prestige pertama untuk jurnal ilmiah (Devos 2011).

Dalam sepuluh tahun terakhir, banyak literatur telah diakses tentang koordinasi program dengan berbagai metode penelitian, namun belum ada analisis bibliometrik mengenai koordinasi program yang dilaporkan dalam publikasi jurnal yang terindeks Scopus. Hal ini dapat diartikan bahwa perlunya penelitian analisis bibliometrik tentang koordinasi program.
Penelitian dengan topik koordinasi program dengan menggunakan metode bibliometrik belum dilakukan, sehingga tidak dapat menemukan contoh artikel dengan topik tersebut. Kebaruan penelitian ini adalah menggunakan metode analisis bibliometrik sehingga penulis ingin mengetahui seberapa besar perkembangan artikel internasional dengan topik koordinasi program dari tahun 1943 hingga 2021. Rumusan masalah dalam penelitian ini adalah sebagai berikut: (1) cara mengutip pasal koordinasi program tahun 1943-2021; (2) bagaimana tren publikasi artikel tentang koordinasi program tahun 1943-2021; (3) bagaimana kerjasama penulis pada pasal-pasal tentang koordinasi program tahun 1943-2021; (4) Apa trend term judul artikel koordinasi program tahun 1943-2021? (5) Bagaimana trend kata kunci pengarang dalam artikel koordinasi program tahun 1943-2021?; (6) Bagaimana tren istilah abstrak dalam pasal-pasal koordinasi program tahun 19432021?; (7) Bagaimana statistik negara pada artikel koordinasi program di tahun 1943-2021?.

\section{Tinjauan Pustaka}

Analisis bibliometrik digunakan untuk melihat sebaran jumlah publikasi dan sitasi dari berbagai literatur (De-Moya-Anegon, F., ChinchillaRodriguez, Z., Corera-Alvarez, E., Munoz- Fernandez and Navarrete-Cortes 2004). Topik dalam analisis bibliometrik dapat dijelaskan baik secara kualitatif dan kuantitatif (Velasco, B., Bouza, J.M.E., Pinilla, J.M., Roman 2012).

Indikator bibliometrik dapat memberikan tingkat perkembangan suatu ilmu pada tingkat yang lebih tinggi dengan melihat sifat dan kemajuan ilmu yang bersangkutan. Keandalan dalam indikator bibliometrik dipengaruhi oleh dua aspek utama, antara lain pemilihan database yaitu banyaknya database bibliometrik, beberapa multi disiplin dan lainnya pada area tertentu serta identifikasi publikasi berdasarkan alamat yang diberikan penulis (Devos 2011). Indikator bibliometrik lebih kuat pada tingkat agregasi yang lebih tinggi dan lebih cocok untuk menganalisis pola dalam kumpulan besar (tim peneliti besar) dan lebih sedikit cocok untuk evaluasi individu atau tim peneliti kecil (Russell, J.M., Rousseau, 2015).

Pencariaan data bibliometric "Coordination Program" dengan menggunakan data scopus. Scopus merupakan database abstrak dan kutipan serta pengindeks yang memuat publikasi ilmiah 
internasional yang bereputasi tinggi. Abstrak dan kutipan merupakan hasil peer-review literatur jurnal, ilmiah, prosiding, buku, dan artikel konferensi lainnya.

Untuk mencari bibliografi sebagai sumber database, peneliti dapat menggunakan Scopus. Pemilihan menggunakan Scopus, karena Scopus merupakan salah satu database (pusat data) kutipan/ literatur ilmiah yang dimiliki oleh penerbit terkemuka dunia yaitu Elsevier. Scopus diperkenalkan secara umum pada tahun 2004. (Chadegani et al, 2011).

Data yang menjadi pusat perhatian dalam analisis bibliometriK cenderung masif (misalnya, ratusan, jika tidak ribuan) dan bersifat objektif (misalnya, jumlah kutipan dan publikasi, kemunculan kata kunci dan topik), meskipun interpretasinya sering bergantung pada evaluasi objektif (misalnya, analisis kinerja) dan subjektif (misalnya, analisis tematik) yang ditetapkan melalui Teknik dan prosedur yang diinformasikan (Donthu et al. 2021).

\section{Metode}

Dalam penelitian ini, peneliti menggunakan data dari publikasi internasional yang bersumber dari database Scopus (www.scopus.com) Pengumpulan data melalui penelusuran dengan keywords "Coordination program". Data yang diperoleh melalui penelusuran pada scopus, kemudian dianalisis menggunakan analisis bibliometrik yang terdiri dari empat langkah yaitu tahap pencarian, tahap filterisasi, pemeriksaan atribut bibliometrik, dan analisis bibliometrik (Julia, J., Supriatna, E., Isrokatun, I., Aisyah, I., Aminat O., A., Hakim 2020). Adapun Langkah-langkah penelitian sebagai berikut.

\section{Tahap Pencarian}

Scopus digunakan untuk mencari bibliografi sebagai sumber database yang akan digunakan. Pilihan menggunakan Scopus adalah karena Scopus merupakan salah satu database terbesar yang menyediakan literatur dan publikasi peer-review. Pada penelitian ini, pencarian bibliografi terbatas pada beberapa aspek. Pertama, jenis bibliografi yang digunakan dalam jenis journal article tittle, abstract, dan keywords. Kedua, key words yang digunakan yaitu "Coordination program". Ketiga, pembatasan dilakukan pada pencarian Bahasa Inggris.

\section{Gambar 1 \\ Pencarian Bibliografi Dalam Aplikasi Scopus}

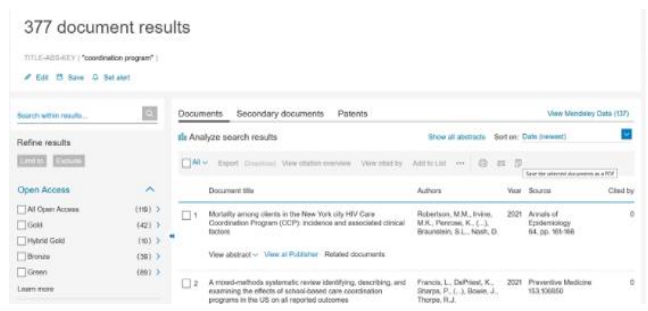

Sumber: www.scopus.com

\section{Tahap Filterisasi}

Pada tahap filtrasi dilakukan pemilihan untuk menyeleksi jurnal yang akan di analisis. Daftar pustaka yang dipilih dan digunakan adalah jenis judul artikel, abstrak, kata kunci, artikel atau review. Pencarian data awal melalui aplikasi Scopus menghasilkan 377 bibliografi, dengan kriteria pencarian terbatas dengan kata kunci "coordination program". Selanjutnya, dilakukan screening terhadap judul artikel yang menggunakan bahasa inggris menghasilkan 355 bibliografi (pada tabel 1).

\section{Tabel 1}

\section{Hasil Pemilihan Bibliografi}

\begin{tabular}{|l|l|l|l|}
\hline $\begin{array}{l}\text { Tahun } \\
\text { Publikasi }\end{array}$ & Terpilih & $\begin{array}{l}\text { Tidak } \\
\text { Terpilih }\end{array}$ & Total \\
\hline 2021 & 22 & - & 22 \\
\hline 2020 & 31 & - & 31 \\
\hline 2019 & 37 & - & 37 \\
\hline 2018 & 24 & - & 24 \\
\hline 2017 & 23 & - & 23 \\
\hline 2016 & 19 & - & 19 \\
\hline 2015 & 24 & - & 24 \\
\hline 2014 & 13 & - & 13 \\
\hline 2013 & 17 & - & 17 \\
\hline 2012 & 9 & - & 9 \\
\hline 2011 & 10 & - & 10 \\
\hline $2010-2000$ & 70 & - & 70 \\
\hline $1999-1943$ & 56 & - & 56 \\
\hline Total & 355 & - & 358 \\
\hline
\end{tabular}




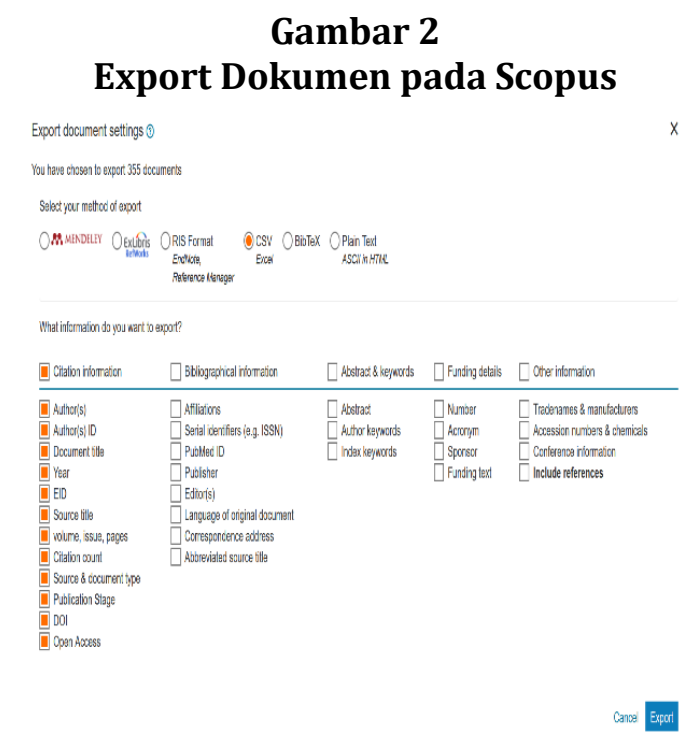

Sumber: www.scopus.com

\section{Tahap Analisis Bibliometrik}

Pada penelitian ini, akan menganasilis berdasarkan tujuh aspek yang terdapat pada rumusan masalah. Dengan analisis blibiometrik diharapkan dapat menjawab pertanyaan pada rumusan masalah yang sudah dikemukakan di awal. Penulis menggunakan aplikasi VOSviewer untuk membantu analisis bibliometrik dengan memvisualisasikan hasil analisis. VOSViewer adalah program komputer yang digunakan untuk memvisualisasikan peta bibliometrik. Fungsi textmining dapat digunakan untuk memvisualisasikan suatu jaringan atau hubungan (co-relation) dalam suatu kutipan artikel.

Analisis bibliometrik ini sangat diuntungkan dari pengolahan data terkomputerisasi dan dalam beberapa tahun terakhir telah terjadi peningkatan besar dalam jumlah publikasi. Selain itu, analisis bibliometrik tidak hanya mengandalkan komputerisasi dalam pengolahannya, namun harus memasukkan volume data tertentu secara berurutan untuk dapat diandalkan secara statistik (Ellegaard and Wallin 2015).

VOSViewer dapat menyajikan dan memvisualisasikan informasi khusus tentang peta grafik bibliometric sehingga lebih mudah untuk menafsirkan suatu hubungan atau jaringan (Jan Van Eck, 2010).

Tahap pertama yang dilakukan pada analisis bibliometrik adalah hasil filter pada scopus yang telah diberikan pembatasan kriteria, lalu dokumen tersebut di export dengan memilih tipe CSV Excel (Gambar 2). Selanjutnya file hasil export tersebut dapat digunakan pada aplikasi VOSviewer.
Tahap selanjutnya adalah pilih create (pada Gambar 3). Lalu pilih create a map base on bibliographic data, klik next, pilih read data from bibliographic database files (Supported file types: Web of Science, Scopus, Dimensions, and PubMed), klik next, pilih scopus, input file yang telah di ekstrak dari scopus (dalam bentuk csv), klik next, kemudian pilih co-occurrenceco-authorship/co citation, klik next, klik finish.

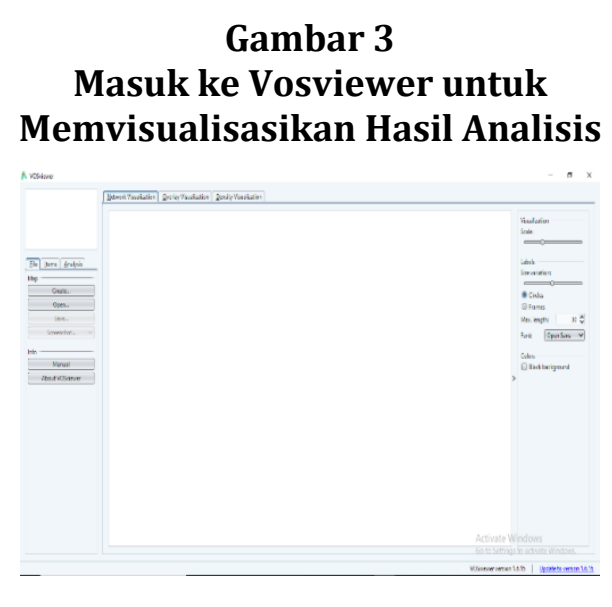

Sumber: www.scopus.com

\section{Hasil dan Pembahasan}

\section{Analisis Sitasi}

Analisis sitasi adalah salah satu dasar sifat karya ilmiah. Hubungan kutipan karya ilmiah adalah dasar utama dari analisis sitasi. Analisis sitasi menggunakan berbagai cara, termasuk matematika, statistik, perbandingan, induksi, abstraksi, generalisasi, dan metode logis. Metode ini digunakan untuk menganalisis berbagai jurnal ilmiah, makalah, objek sitasi, dan fenomena yang dikutip untuk menentukan karakteristik yang melekat dari metode analisis bibliometrik. Analisis sitasi diperkenalkan pada tahun 1920-an. Pada tahun 1927, Gross et al. melakukan analisis sitasi pertama dalam sejarah sastra. Mereka menganalisis referensi dari artikel di beberapa majalah teknik kimia dan majalah inti dalam pendidikan kimia.Semakin banyak makalah tentang analisis kutipan telah disajikan di bidang bibliometrik. Metode ini dapat diterapkan secara efektif untuk banyak area dengan praktik, dan itu memainkan peran yang semakin penting (Qiu et al. 2017).

Salah satu cara untuk menilai kualitas publikasi ilmiah adalah dengan menghitung berapa kali karya tersebut dikutip oleh peneliti lain. Kutipan suatu karya ilmiah berarti memiliki arti yang bermanfaat dalam bidang ilmu pengetahuan (Benjamin, 2012, Erwina, Wina, Kurniasih, N., 2010, Oregon State University, 2011). Seberapa sering sebuah karya dikutip menunjukkan bahwa seberapa sering karya tersebut menjadi bahan diskusi di antara para 
ilmuwan (Benjamin 2012). Dalam penelitian ini, hasil analisis sitasi menunjukkan bahwa jumlah sitasi per tahun dari tahun 1943-2021 adalah 4.304 kutipan/sitasi. Pola kutipan menunjukkan pola yang berbeda-beda. Jika dilihat pertahun, maka paling banyak kutipan terjadi pada tahun 2021 yaitu sebanyak 607 kutipan.

\section{Analisis Tren Publikasi}

Produktivitas 10 peneliti teratas dengan topik coordination program tahun 1943-2021 yang terindeks Scopus menunjukkan produktivitas peneliti berkisar antara 5-10 publikasi. Berdasarkan grafik 2, terlihat bahwa peneliti Irvine, M.K memiliki produktivitas terbesar yaitu sebanyak 10 publikasi, sedangkan yang terkecil yaitu peneliti Kalman, L dan Hawkins, $\mathrm{K}$ yaitu masing - masing sebanyak 5 publikasi. Peneliti Nash, D sebanyak 9 publikasi, Braunstein, S.L sebanyak 8 publikasi, Kalman, L.V dan Penrose, $\mathrm{K}$ sebanyak masingmasing 7 publikasi. Peneliti Harriman, G, Pratt, V.M dan Toji,L sebanyak masing-masing 6 publikasi.

\section{Grafik 1}

\section{Penulis Terbesar Publikasi Artikel Koordinasi Program dari Tahun 1943- \\ 2021}

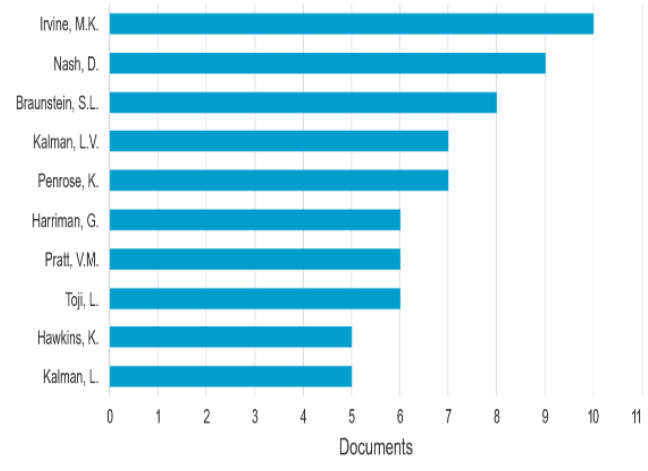

Sumber: www.scopus.com

\section{Analisis Subjek Area}

Berdasarkan grafik dapat dilihat 3 subjek area terbesar yaitu medicine sebanyak $43 \%$ atau 225 dokumen, nursing sebanyak 10,7 \% atau 56 dokumen dan engineering sebanyak 8,0 \% atau 42 dokumen dapat dilihat pada diagram 1 .

\section{Diagram 1 \\ Subjek area dengan topik Koordinasi \\ Program Dari Tahun 1943-2021}

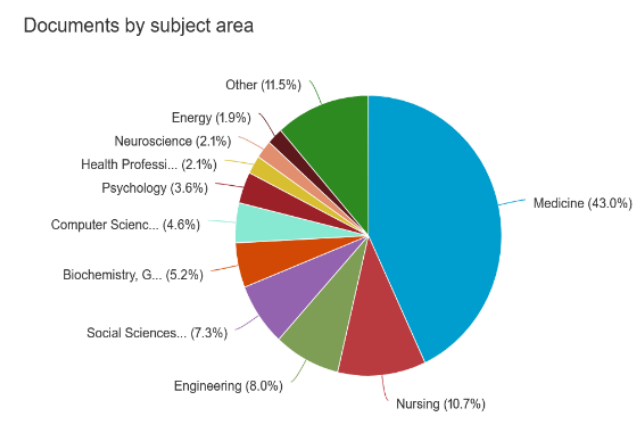

Sumber: www.scopus.com

\section{Analisis Kolaborasi Author}

Kolaborasi dalam penelitian sangat diharapkan, karena penelitian tidak selalu dilakukan secara individu (Rohanda, Winoto 2019). Untuk itu diperlukan kerjasama antara peneliti dan antar instansi baik dari segi ide, dana, sarana dan prasarana serta kesempatan untuk berbagi ilmu, dan teknik tertentu dalam suatu ilmu (Widuri 2018). Dalam penelitian ini, dari 1.486 penulis, 13 penulis memiliki hubungan yang kuat. Setiap penulis di setiap grup tautan berbeda. Penulis yang memiliki tautan terbanyak adalah Irvine, M.K.

\section{Gambar 4 \\ Visualisasi Kolaborasi Penulis}

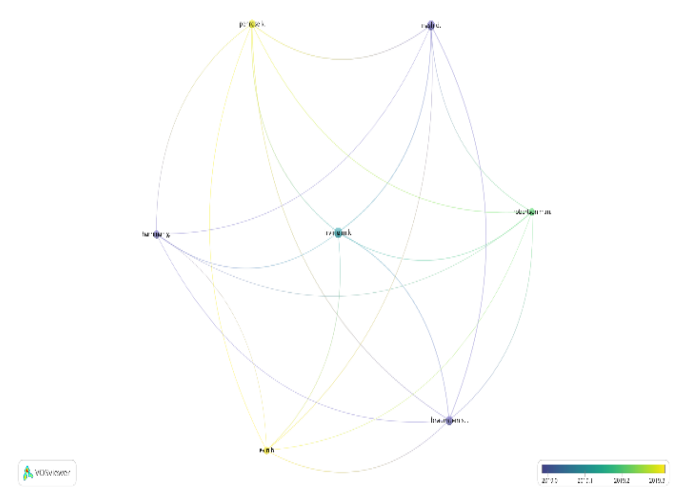

Sumber: VOSviewer

\section{Analisis Trend Terms Judul}

Pada tahap analisis ini bertujuan untuk menganalisis isi, pola dan tren (tren) dari kumpulan dokumen dengan mengukur kekuatan istilah (terms) dan menghitung jumlah kata kunci yang muncul secara bersamaan dalam artikel yang diteliti (Chen, 2003, Russell, J.M., Rousseau, 2015). Terdapat 2.870 kata kunci, menggunakan jumlah kemunculan minimum dari 5 syarat, maka hasilnya 
ditemukan sebanyak 263 yang relevan. Terdapat 8 cluster, kluster 1 berwarna merah sebanyak 49 jenis, kluster ke 2 berwarna hijau sebanyak 43 jenis, kluster 3 berwarna biru sebanyak 38 jenis, kluster 4 berwarna kuning sebanyak 35 jenis, kluster 5 berwarna ungu sebanyak 33 jenis, kluster 6 berwarna biru muda sebanyak 26 jenis, kluster 7 berwarna orange sebanyak 22 jenis dan kluster 8 berwarna coklat sebanyak 16 jenis. Istilah pada judul yang paling banyak digunakan dalam artikel koordinasi program adalah "human" dengan total 224 peristiwa (Gambar 5).

\section{Gambar 5 \\ Visualisasi Istilah Dalam Judul Artikel Koordinasi Program}

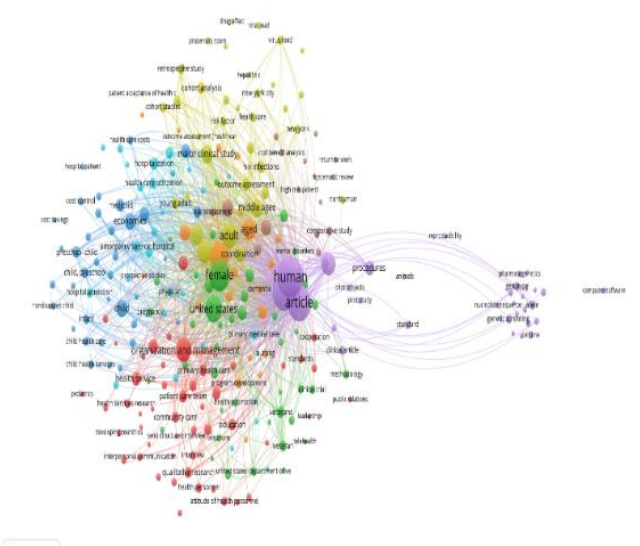

\section{Sumber: VOSviewer}

\section{Analisis Trend Trems Author Keywords}

Pada tahap analisis trend terms, ditemukan bahwa 676 kata kunci penulis digunakan dalam artikel yang dipilih dan dengan menggunakan minimal 5 peristiwa, 9 kata kunci penulis memiliki hubungan yang kuat. Istilah 'perawatan koordinasi' adalah istilah yang paling sering digunakan oleh penulis sebanyak 23 saluran, diikuti dengan istilah "care coordination" dengan 8 terusan. Istilah "hiv" adalah istilah yang paling jarang digunakan dengan 4 terusan (Gambar 6).

\section{Gambar 6 \\ Visualisasi Jaringan Kata Kunci Penulis Artikel Koordinasi Program}

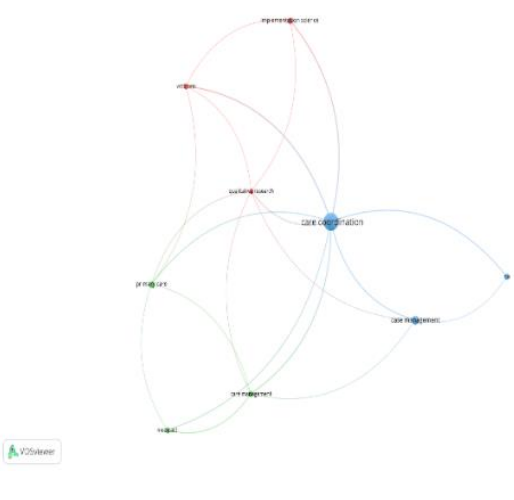

Sumber: VOSviewer

\section{Analisis Trend Trems Abstrak}

Berdasarkan analisis istilah yang sering digunakan dalam abstrak artikel koordinasi program sebanyak 2.397 kata kunci, sebanyak 488 istilah yang memiliki tautan kuat, dengan analisis menggunakan jumlah kemunculan minimum 3 istilah. Terdapat 10 kluster, dengan rincian: kluster 1 berwarna merah sebanyak 73 jenis, kluster 2 berwarna hijau sebanyak 71 jenis, kluster 3 berwarna biru sebanyak 68 jenis, kluster 4 berwarna kuning sebanyak 56 jenis, kluster 5 berwarna ungu sebanyak 50 jenis, kluster 6 berwarna biru muda sebanyak 45 jenis, kluster 7 berwarna orange sebanyak 43 jenis, kluster 8 berwarna coklat sebanyak 40 jenis, kluster 9 berwarna merah muda sebanyak 39 jenis, dan kluster 10 berwarna hitam sebanyak 3 jenis. Istilah yang paling banyak digunakan dalam abstrak yang memiliki relevansi adalah 'human' dengan 224 kejadian, 'humans' dengan 186 kejadian, 'article' dengan 169 kejadian, dan 'female' dengan 134 kejadian (Gambar7). 


\section{Gambar 7 \\ Jaringan Abstrak Istilah pada Artikel Koordinasi Program}

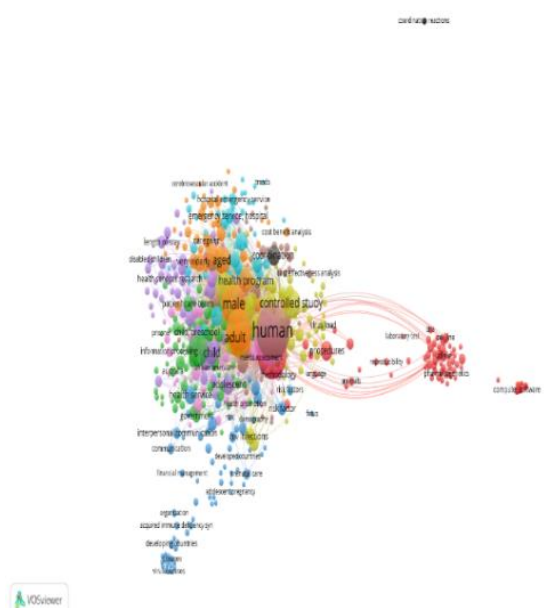

Sumber: VOSviewer

\section{Analisis Statistika Negara}

Kontributor hasil penelitian dalam artikel koordinasi program pada aplikasi Scopus, dapat diidentifikasi bahwa penulis artikel koordinasi program tersebar di berbagai negara. Negara terbanyak yang mengeluarkan artikel koordinasi program adalah United States dengan 246 artikel, Canada dengan 17 artikel, dan Australia dengan 13 artikel (diagram 2).

\section{Diagram 2 Distribusi Penulis Menurut Negara}

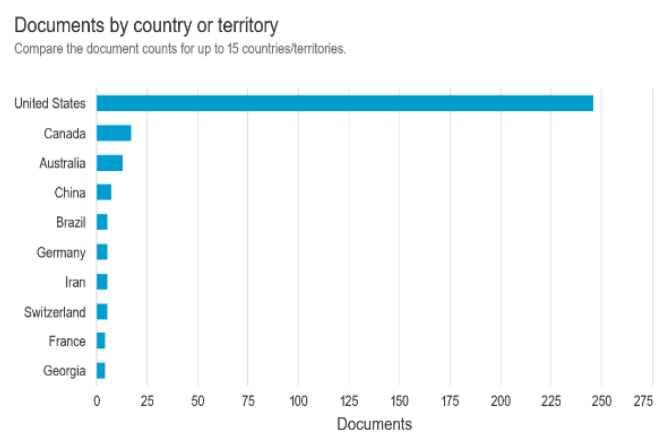

Sumber: www.scopus.com

\section{Dokumen Affiliation}

Gambar 8 menunjukkan bahwa affiliation pada penelitian koordinasi program terdapat 10 besar antara lain: VA Medical Center, New York City Department of Health and Mental Hygiene, The University of North Carolina at Chapel Hill, Centers for Disease Control and Prevention, City University of New York, Johns Hopkins Bloomberg School of Public Health, Icahn School of Medicine at Mount Sinai, Johns Hopkins School of Medicine, University of Pennsylvania, dan Coriell Institute for Medical Research.

\section{Gambar 8}

Dokumen Affiliation Koordinasi Program

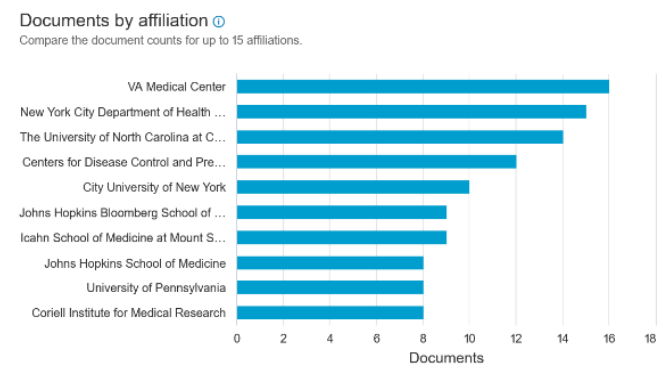

Sumber: www.scopus.com

\section{Simpulan}

Analisis bibliometrik adalah metode ilmiah yang dapat berguna bagi para peneliti yang ingin mengejar retrospektif bidang yang luas dan kaya dalam penelitian. Metodologi bibliometrik telah mendapatkan popularitas besar akhir-akhir ini karena kemahahadiran dan kegunaan perangkat lunak dan basis data bibliometrik yang memudahkan perolehan dan penilaian volume besar data ilmiah. Aplikasi bibliometrik yang penting dan relatif baru adalah dalam koordinasi program.

Berdasarkan hasil dan pembahasan dapat disimpulkan bahwa publikasi tentang koordinasi program selama periode 1943-20201 menunjukkan indeks Scopus tertinggi terjadi pada tahun 2019 yang mencapai 37 publikasi.Negara-negara yang menerbitkan artikel koordinasi program paling banyak adalah United States. Irvine, M.K merupakan peneliti yang memiliki produktivitas terbesar yaitu sebanyak 10 publikasi. Pada analisis tern judul, terbentuk 8 cluster. Istilah dalam judul yang paling banyak digunakan dalam artikel koordinasi program adalah "human" dengan total 224 peristiwa. Penulis menyarankan perlunya penambahan kata kunci baru untuk mendapatkan hasil penelitian yang lebih banyak sehingga lebih komprehensif.

\section{Daftar Pustaka}

Benjamin, M. 2012. "Citation Analysis."

Bouckaert, Geert, B. Guy Peters, and Koen Verhoest. 2010. The Coordination of Public Sector Organizations.

Chen, C. 2003. Mapping Scientific: The Quest For Knowledge Visulization. London: SpringerVerlag.

De-Moya-Anegon, F., Chinchilla-Rodriguez, Z., Corera-Alvarez, E., Munoz- Fernandez, F. J., 
and J. Navarrete-Cortes. 2004. "Indicadores Bibliometricos de La Actividad Cientifica Espanola: (ISI, Web of Science, 1998-2002) [Bibliometric Indicators of Spanish Scientific Activity: (ISI, Web of Science, 1998-2002)]." FECYT-Ministerio de Educacion y Ciencia.

Devos, P. 2011. "Research and Bibliometrics: A Long History..." Clinics and Research in Hepatology and Gastroenterology 35(5):336-37.

Donthu, Naveen, Satish Kumar, Debmalya Mukherjee, Nitesh Pandey, and Weng Marc Lim. 2021. "How to Conduct a Bibliometric Analysis: An Overview and Guidelines." Journal of Business Research 133(March):28596.

Ellegaard, Ole, and Johan A. Wallin. 2015. "The Bibliometric Analysis of Scholarly Production: How Great Is the Impact?" Scientometrics 105(3):1809-31.

Erwina, Wina, Kurniasih, N., Yulianti. 2010. Analisis Sitasi Karya Dosen Fikom Pada Database GDL. Bandung: Universitas Padjadjaran.

Julia, J., Supriatna, E., Isrokatun, I., Aisyah, I., Aminat O., A., Hakim, A. 2020. "Moral Education (2010-2019): A Bibliometric Study (Part 2)." Universal Journal of Educational Research 8:2954-2968.
Marume, S. B. M., and E. Jaricha. 2016. "Coordination As An Essential Part of Public Administration." Journal of Research in Humanities and Social Science 4(6):6-9.

Oregon State University. 2011. What Is a Citation?

Qiu, Junping, Rongying Zhao, Siluo Yang, and Ke Dong. 2017. Informetrics: Theory, Methods and Applications.

Rohanda, Winoto, Y. 2019. “Analisis Bibliometrika Tingkat Kolaborasi, Produktivitas Penulis, Serta Profil Artikel Jurnal Kajian Informasi \& Perpustakaan Tahun 2014- 2018." PUSTABIBLIA: Journal of Library and Information Science 3:1-15.

Russell, J.M., Rousseau, R. 2015. Bibliometrics and Institutional Evaluation.

Tachjan. 2006. Implementasi Kebijakan Publik. Bandung: AIPI Bandung.

Velasco, B., Bouza, J.M.E., Pinilla, J.M., Roman, J. A. S. 2012. "La Utilizacion de Los Indicadores Bibliometricos Para Evaluar La Actividad Investigadora." Aula Abierta 40, 75-84.

Widuri, N. .. 2018. "Tingkat Kolaborasi, Produktivitas Penulis Dan Artikel Metrik Pada Jurnal." Jurnal Berkala Ilmu Perpustakaan Dan Informasi. 